Kinestetik : Jurnal Ilmiah Pendidikan Jasmani 5 (4) (2021)

Kinestetik : Jurnal Ilmiah Pendidikan Jasmani

https://ejournal.unib.ac.id/index.php/kinestetik/index

DOI : 10.33369/jk.v5i4.19546

\title{
STUDENT ATHLETE REWARDING SYSTEM IN BANDUNG CITY
}

\author{
Nuryadi $^{\text {**, Bambang Abdul Jabar }}{ }^{2}$, Jajat Darajat KN³ ${ }^{3}$, Agus Gumilar ${ }^{4}$, Burhan \\ Hambali $^{5}$ \\ ${ }^{12345}$ Department of Sports Education, Faculty of Sports and Health Education, Universitas \\ Pendidikan Indonesia, Bandung, Indonesia
}

\section{Article Info}

Article History : December 2021

Received : December 2021

Revised : December 2021

Accepted : December 2021

Available online : December 2021

Keywords:

Student Athlete, Reward Sistem, Career Development

\section{Abstract}

At the 2018 West Java Regional Sports Week, there were 1,822 athletes, mechanics, managers and officials involved. Researchers here review and conduct surveys and interviews with athletes and Koni West Java regarding the awards given to student athletes. Athlete career development is manifested in the form of educational scholarships for athletes within the Bandung City KONI from $2019-2021$, with the following percentages in 2019 of $33 \%$, in $202033 \%$, and in 2021 as much as $34 \%$ of the total scholarship budget that has been issued since 2019-2021 years. Scholarship recipients within the KONI Bandung City are tiered starting from the Middle School, Undergraduate, and Masters programs, through this student athlete program it is hoped that athletes will get decent jobs, so that after athletes retire from the world of sports they will get welfare in retirement. 


\section{INTRODUCTION}

The goal of competitive sports is to achieve the highest achievement, namely to win the championship and get a gold medal (Nuryadi et al., 2020) . Elite, olympic, and professional athletes in contemporary sports are fully devoted to being superior and the best in their sport (Aquilina, 2013). The implementation of competitions in competitive sports carried out by sports organizations every year always increases, whether it's an event on a regional, national, or international scale. The implementation of multi-events in Indonesia itself has several levels, at the regional level there is the Provincial Sports Week (PORPROV) and at the national level the National Sports Week (PON) which is held every four years. (Nuryadi et al., 2020).

Multi-event events such as PON involve many athletes who compete, of course, they must also think about how their lives will be after becoming athletes. Athletes have struggled for decades to decades to fill their lives for the pride of themselves and their nation. During their prime, they were greatly admired and hailed by the public because of the status they held as athletes. All life while being an athlete is fulfilled, from salary, transportation, to accommodation. Now many of them have neglected their lives after becoming athletes (Nuryadi et al., 2019). Of course, while being an athlete, what is expected is to get achievements by winning as many medals as possible to get bonuses in the form of coaching money from the government. Finally, the final cessation of an athlete's career is not a matter of bonuses but is marked by leaving the world of competitive sport and by a transition to another, namely a career in the form of work, the need to adjust to a new status, lifestyle, and social network.. Athletes need planning in their careers after retirement, they also have a great interest in planning future careers while still active as athletes $(\mathrm{N}$. Stambulova, 2010). Athletes tend to have a low level of awareness regarding career planning during their careers (Lavallee, 2006), they are more likely to think about the achievements to be achieved than to think about their post-retirement career as athletes. In China On average 3000 Chinese athletes quit or retire from provincial level athletes or the national team, and only 10 percent are employed or seconded by the government. They have to wait a year or two to get a job (Liu \& Lu, 2016).

The Indonesian government has a program for the appointment of civil servants through the athlete route but it is very limited, in 2018 as many as 138 athletes were appointed as civil servants by the Ministry of State Apparatus Empowerment and Bureaucratic Reform as well as the Ministry of Youth and Sports (daily tempo, 2018). However, those who are appointed and awarded by the government are only athletes who are selected and have the highest achievements. Then how do other outstanding athletes get jobs and develop careers after retiring to become athletes. National data states that in the 2018 Asia Games where Indonesia hosted 1,303 athletes and coaches fighting to defend their homeland to achieve achievements, it means that only $10.5 \%$ of athletes and coaches are rewarded and given jobs by the government, then how do other athletes get a job? profession. One of the main problems in the development of national sports is the unstructured award system given in Indonesia (Ma'mun, 2016). Post-athlete career is a phenomenon that attracts public attention. Not only in terms of success but also in terms of failure, ex-athletes in life are retired from status as athletes. Athletes have struggled for decades to decades to fill their lives for the pride of themselves and their nation (Nuryadi et al., 2020). The five main factors that hinder athletes' 
careers are career development selfefficacy, career versus sport identity, locus of control, career development barriers, and the relationship between sport and work. (Sandstedt et al., 2004).

\section{METHOD}

The method used in this research is descriptive quantitative survey analysis research method, survey research is research to collect information from a sample by collecting data through questionnaires or interviews so that it can describe aspects of the population. The survey was conducted on athletes, former athletes and sports coaches to reveal how awards are given in the academic field to student athletes in Bandung city. The samples in this study were athletes, former athletes and coaches in the city of Bandung. Athletes and former athletes in the environment and under the guidance of Bandung city. At the 2018 West Java Regional Sports Week, there were 1,822 athletes, mechanics, managers, and officials involved. The researcher here reviews and conducts surveys and interviews with athletes and Koni West Java regarding the awards given to student athletes.

\section{Population and Sample}

The population and sample in this study were athletes, former athletes and coaches in the city of Bandung. Athletes and former athletes in the environment and under the guidance of Bandung city. At the 2018 West Java Regional Sports Week, there were 1,822 athletes, mechanics, managers, and officials involved. The researcher here reviews and conducts surveys and interviews with athletes and Koni West Java regarding the awards given to student athletes.

\section{Instrument}

The instrument used in this study was structured interviews with athletes, coaches, and administrators of the Bandung City KONI. The interviews conducted were related to how awards are given to athletes and coaches as well as to reveal patterns of athlete career development, one of which is in encouraging athletes to get a proper education.

\section{Design or Data Analysis}

The analysis in this study used descriptive statistics and percentages. The survey results obtained data related to student athletes assisted by Koni City of Bandung, especially in the field of Career Education (Student Athlete) in the form of educational scholarships. The following is the percentage of athlete scholarship recipients who are in the Bandung City KONI environment since 2019-2021:

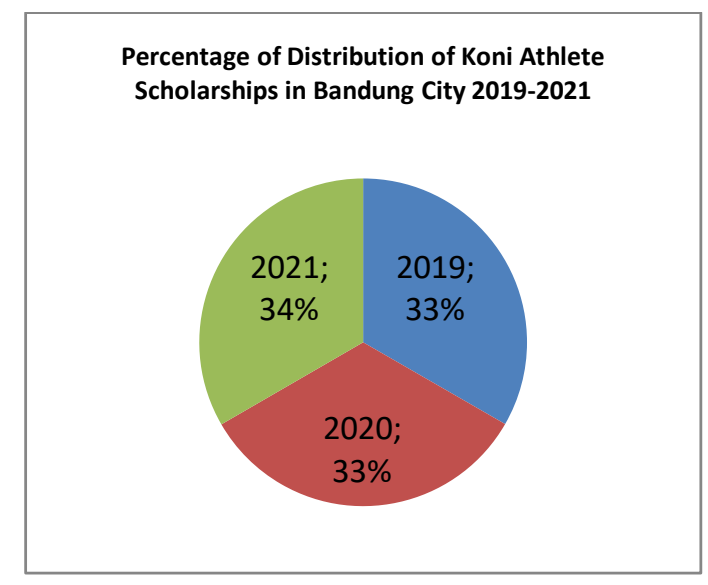

Picture 1. Bandung City Koni Athlete Scholarship Distribution

Since 2019-2021 Bandung city City has distributed educational scholarships to athletes in the city of Bandung, namely in 2019 by $33 \%$, in 2020 by $33 \%$, and in 2021 as much as 34\% of the total scholarship budget that has been disbursed since 2019-2021. 


\section{RESULT AND DISCUSSION}

The National Sports System in it regulates the roles and responsibilities of the government towards athletes in Indonesia. The intended responsibility is how the government must fulfill the needs and rights of athletes in Indonesia, both in their social life and their training needs (UU No 3 Tahun 2005, 2005). The role of the government in athletes' careers is very important, athletes must be given guidance and support both morally and materially in terms of athlete careers. The athlete's career transition after retiring from the sport has been a difficult and disturbing process for many athletes.

Koni Kota Bandung hopes that the coaching of Student Athletes can be a provision for athletes after retirement to become athletes and their welfare is guaranteed. Retirement is a scary thing for athletes, career transition and handling models for athletes and former have been carried out by world researchers, among others; 1) Atchley expressed continuity theory: retirement is seen as a process in the continuity of past roles 2) Rosenberg suggests that retiring from a sporting career can be likened to the figurative "social death," which is characterized by isolation and rejection from the group to which the athlete belongs; dan 3) Werthner $\&$ Orlick's research found $78 \%$ of Canada's elite athletes experience emotional difficulties after leaving the sport and 32\% describe the transition as "extremely difficult. 5) Elite athletes in their careers will face 6 transitions, and the most critical period is the end of achievement (towards retirement) and post-athlete. (N. Stambulova, 2010; N. Stambulova et al., 2009; N. B. Stambulova \& Wylleman, 2015).

\section{CONCLUSION}

Referring to all the results of a survey of athletes in the Bandung City Koni environment showing positive results, this shows that the athlete's response to athlete career development for student athletes is very positive and supports $100 \%$ of the athlete's career development pattern. that athlete career development is realized in the form of educational scholarships for athletes within the Bandung City KONI from 2019-2021, with the following percentages in 2019 of $33 \%$, in 2020 $33 \%$, and in 2021 as much as $34 \%$ of the total scholarship budget that has been disbursed from 2019-2021. Recipients of scholarship assistance within the Bandung city City range from Middle School, Undergraduate, and Masters programs, through the student athlete program it is hoped that athletes will get decent jobs, so that after athletes retire from the world of sports, they will get prosperity in their retirement period.

\section{ACKNOWLEDGEMENT}

The authors would like to thank all parties who have supported the research and writing of this article, namely Bandung city City, University of Education Indonesia, as well as athletes and coaches who have taken the time to provide information for this research. We hope that studies related to the award system for athletes can run continuously in an effort to provide a decent life after retirement.

\section{REFERENCES}

Aquilina, D. (2013). A study of the relationship between elite athletes' educational development and sporting performance. International Journal of the History of Sport. https://doi.org/10.1080/09523367.2013. 
765723

Fadilah, R. N. (2020). Laporan Praktik Kerja Lapangan Pada Asisten Deputi Penghargaan Olahraga Kementerian Pemuda Dan Olahraga.

Guspa, A., \& Rahmi, T. (2017). Hubungan antara persepsi terhadap financial reward dengan komitmen kerja pada Atlet. Jurnal RAP (Riset Aktual Psikologi Universitas Negeri Padang), 5(1), 1-11.

Jibrel, A. (2019). Hubungan Financial Reward dengan Komitmen Organisasi Pada Atlet IPSI Surabaya (Doctoral dissertation, UIN Sunan Ampel Surabaya).

Liu, Z., \& Lu, Y. (2016). Re-employment of retired athletes in China. The International Journal of the History of Sport, 33(5), 624-633.

Ma'mun, A. (2016). Pembudayaan Olahraga dalam Perspektif Pembangunan Nasional Konsep, Strategi, dan Implementasi Kebijakan. Jurnal Pendidikan Sains Sosial Dan Kemanusiaan, 9(1), 65-88.

Nuryadi, N., Hidayat, Y., Budiana, D., \& Darajat KN, J. (2020). Career Development Model and Awarding System for Athletes and Former Athletes in Indonesia. 21(Icsshpe 2019), 53-54. https://doi.org/10.2991/ahsr.k.200214.0 15

Nuryadi, N., Hidayat, Y., Budiana, D., \& Negara, J. D. K. (2019). Analysis of Former Athlete Coaching Model in Indonesia: A preliminary study. https://doi.org/10.2991/icsshpe18.2019.109

Permatasari, N. (2017). Pengaruh Total Quality Management, Budaya Organisasi, Dan Sistem Penghargaan Terhadap Kinerja Manajerial (Doctoral dissertation, Universitas Katolik Musi Charitas).

Roni, F., Sulastri, S., \& Muktamar, R. N. Pengaruh Penghargaan Finansial, Lingkungan Kerja Dan Motivasi Terhadap Minat Memilih Profesi Atlet Sepakboladi Provinsi Sumatera Selatan. Jurnal Ilmu Keolahragaan, 20(1), 79-85.

Silaban, E. L., Saptawan, A., \& Novida, E. (2020). Evaluasi Implementasi
Peraturan Presiden No 44 Tahun 2014

Tentang Pemberian Penghargaan

Terhadap Peningkatan Prestasi Olahraga

Di Kabupaten Ogan Komering Ulu

(Doctoral Dissertation, Sriwijaya University).

Sirait, J., \& Noer, K. U. (2021). Implementasi Kebijakan Keolahragaan Dan Peran Pemangku Kepentingan Dalam Peningkatan Prestasi Atlet. Jorpres (Jurnal Olahraga Prestasi), 17(1), 1-10.

Stambulova, N. (2010). Counseling Athletes In Career Transitions: The Five-Step Career Planning Strategy. Journal Of Sport Psychology In Action. Https://Doi.Org/10.1080/21520704.201 0.528829

Stambulova, N. B., \& Wylleman, P. (2015). Dual Career Development And Transitions. In Psychology Of Sport And Exercise. Https://Doi.Org/10.1016/J.Psychsport.2 015.05.003

Utomo, D. P. Olahraga Dan Politik: Studi Implementasi Kebijakan Terhadap Penghargaan Atlet Berprestasi (Bachelor's Thesis, Jakarta: Fakultas Ilmu Sosial Dan Ilmu Politik Uin Syarif Hidayatullah). 